\title{
Burning Witches: The Moral Dilemmas of Ashaninka Leaders
}

\author{
Enrique Delgado Ramos ${ }^{1}$ and Susana Frisancho \\ Pontifical Catholic University of Peru, Peru
}

\begin{abstract}
This paper focuses on the moral reasoning of Ashaninka leaders about the burning of witches, a cultural practice that has received scant attention from intercultural scholars. We first contextualize burning witches as a cultural practice of the Ashaninka people. Then, based on qualitative interviews, we present the experience of six Ashaninka leaders with witchcraft and witchcraft accusations, as well as their moral reasoning about the social mechanisms that the Ashaninka people have traditionally used to control evil sorcery. The participants are three men and three women from the Ucayali and Junín regions in Peru's Amazon basin. Finally, we discuss intercultural moral education and the need to analyze the reasons behind cultural practices in order to understand the rationality and reasonableness of others.
\end{abstract}

Keywords: Ashaninka people, moral dilemmas, sorcery accusations.

In contemporary societies, hegemonic non-indigenous discourse often blames social problems such as environmental destruction, migration, ethnic nationalism, and the violation of minority rights on cultural differences, as many social narratives depict indigenous peoples as useless, disease-ridden, opposed to development, and unfit for modern life, and assign no value to their way of life (Espinosa, 2009; Kowal \& Paradies, 2005; Vigil, 2010). Intercultural education is often posited as a tool to help students understand cultural differences and to promote relationships of fairness among culturally diverse groups, rendering them equal interlocutors in public space (Sani, 2015; United Nations Educational, Scientific and Cultural Organization [UNESCO], 2006).

In Peru, intercultural education is made necessary by both the country's cultural diversity and its long history of denying it. With at least 55 different ethnic groups living in its territory (Peru. Ministry of Culture, 2020), Peru is a country of great inequality, long-standing social conflicts, and continued violations of original people's rights (Espinosa, 2003, 2009; Portocarrero, 2007; Vigil, 2010).

Because intercultural education in Peru usually focuses on linguistic and folklore-related aspects, it does not address intercultural and moral conflicts (Frisancho \& Delgado, 2018; PeruMinistry of Education, 2013, 2016; Tubino, 2015). In an earlier work (Frisancho \& Delgado, 2018), we argued for the need to bring intercultural moral dilemmas into moral education, with a critical intercultural perspective (Tubino, 2015) that takes into account not only cultural diversity and the importance of dialogue, but also matters of power and justice, which is to say, the conditions under which such dialogue occurs. This includes paying attention to intercultural relationships in the research process itself.

${ }^{1}$ Corresponding Author E-Mail: gdelgado@pucp.edu.pe 
Also based on a critical intercultural framework, we now focus on a specific case, the Ashaninka cultural practice of burning witches, to highlight its rationality and the moral conflicts that Ashaninka people grapple with around it. As will be seen, this practice cannot be understood in isolation from the contexts of exploitation and subordination in which it occurs.

\section{General Context: Witchcraft and Sorcery as Part of Daily Life}

Throughout history, accusations of sorcery have tended to occur in times of social stress (Chauvelot, 1995/2001; Santos-Granero, 2002, 2004). They are often connected to death, illnesses, poverty, hunger, and other ailments. Because people often assume punishment will work as a deterrent, and because social groups have seen the identification and punishment of sorcerers as a way to solve the problems they purportedly create, the accused are frequently subjected to physical violence and severe social consequences (Chauvelot, 1995/2001; Csordas, 2013; Hermkens, 2015; Jamieson, 2008; La Serna, 2011; Santos-Granero, 2002, 2004; Wedel, 2010). Neither social crises nor sorcery accusations are matters of the past; witch-hunting and the persecution of sorcerers remain current practices in different parts of the world.

For instance, accusations of sorcery sometimes still lead to torture and violent death in Papua New Guinea, especially for women (Davidson, 2018; Lallanilla, 2013), while in Tanzania, almost 500 women accused of practicing witchcraft were killed during the first half of 2017, in some cases by being burned alive (Makoye, 2017). Indeed, witchcraft is still seen in Tanzania as a sign of ignorance, to be countered by the introduction of scientific literacy (von Dacre, 2019). Some years ago, a report by Save the Children (Aguilar, 2005), titled The invention of Child witches in the Democratic Republic of Congo, linked the stigmatization of children to the fraying of family structures, widespread illness, increased poverty, and social crises occurring in the country. In many parts of Africa, accusations of witchcraft are still a reality in 2020; in fact, they have been on the rise during the coronavirus pandemic (Humanist International, 2020; Müller \& Sanderson, 2020). In Latin-American countries like Peru, Paraguay, and Nicaragua, several reports have recently appeared in the mass media describing the execution by burning of individuals accused of witchcraft or demonic possession (Associated Press, 2016; Baral, 2014; Schmidt, 2017).

Before Whitehead's \& Wright's (2004) book, most studies of witchcraft in the Amazonian region focused on shamanism (Erikson, 2016). Since then, sorcery and witchcraft among Amazonian indigenous peoples have gained greater prominence in research ethnographies, as a topic of discussion in the media, and as a concern among politicians. For instance, Garra (2016) studied the "official certificates" that Awajun ${ }^{2}$ shamans and other Awajun authorities —and sometimes even national representatives - grant certain individuals in order to distinguish benign shamans and healers (iwishin) from those who do harm (tunchi, "sorcerer"). This provides the former with a protective mechanism against the violence often inflicted on the latter. Another example of witch hunting appears in "Soy Sontone" (Sueyo \& Sueyo, 2017), where a Harakbut man recounts how he allowed his wife to be killed, believing her to be a witch who was secretly harming him, and discusses his feelings of remorse.

In summary, sorcery is a complex phenomenon, impacted by many social, cultural, political and economic tensions and, of course, by psychological and moral conflicts as well. In the next

\footnotetext{
2 The Awajun (formerly known as Aguaruna) are a Peruvian Amazonian indigenous group who speak Awajun, a Jivaroan language. They live primarily along the Marañón River in northern Peru, near the Ecuadorian border.
} 
section, we present the specific role that sorcery and witchcraft play in the cultural universe of the Ashaninka people.

\section{Witchcraft Among the Ashaninka People: Ethnographic Considerations}

With a current population of 114,000 individuals (Peru. Ministry of Culture, 2020) living in 6 areas of the country, the Arawakan-speaking Ashaninka are the largest Amazonian indigenous group in Peru. They suffered greatly during Peru's internal armed conflict (1980-2000), the episode of violence against the Peruvian State initiated by the Maoist organization known as the Shining Path. According to the Truth and Reconciliation Commission (CVR) set up to investigate the period, the Shining Path unleashed a campaign of brutal terror against the Ashaninka. Specialists estimate that, out of a population of 55,000 at the time, 6,000 Ashaninka died and 10,000 were forcibly displaced; meanwhile, between 30 and 40 Ashaninka communities disappeared (Comisión de la Verdad y Reconciliación [CVR], 2003).

Santos-Granero (2002) has pointed out that in the mid-1990s', as the internal armed conflict raged, many researchers reported the resurgence of sorcery accusations against children in Arawakan communities. This resonates with what Chauvelot (1995/2001) noted for Europe: that witchcraft " . . . has appeared sporadically, in various places, responding directly to a brutal deterioration of everyday life: after a plague, a famine, an invasion (...) witchcraft appears as the daughter of misery" (p. 61).

This is precisely what Santos Granero $(2002,2004)$ identifies among four indigenous groups in the Arawak linguistic family among which the execution of children accused of sorcery is common: the Ashaninka, the Asheninka, the Nomatsiguenga, and the Yanesha. Contrary to the usual assumptions, Santos Granero shows that accusations of witchcraft against children are not an ancestral practice, but a tragic consequence of colonization and its complex historic, sociocultural, and demographic processes. Such accusations have been reported in these indigenous groups since the late Nineteenth Century, usually in situations of social turmoil, land dispossession, violence, and epidemics.

To understand witchcraft in the Ashaninka's cultural context, a familiarity with the belief systems traditionally used for the social control of people's behavior is equally important. According to Rojas (1994, 2014), social control in Ashaninka society — which lacks institutions and agencies such as the police - is carried out through specific customs, norms, and mores like a belief in the punishment-dispensing powers of spiritual beings (for instance, when people hunt or fish in excess), or in sorcery and witchcraft.

An Ashanika shaman (known as sheripiari) has the power to identify the sorcerer (matsi or matsinti), an important skill in a cultural setting where sickness and death are seen as moral rather than natural events (Rojas, 1994). The Ashaninka believe that people are perpetually haunted by demonic entities who harm and kill humans by different means (Rojas, 1994, 2014). Sickness and death are attributed to the actions of a matsi. Since being singled out as a matsi can severely imperil the well-being of a person and their family, such beliefs promote conformity to social norms. So, according to Rojas, accusations of sorcery are made only in extreme circumstances; it is far more common for the sheripiari to help the accused modify his or her behavior. The ethnographic literature (Santos-Granero, 2002, 2004) shows that accusations of sorcery are made mainly, although not exclusively, against the group's weakest members, such as young girls or orphaned 
children. As Santos-Granero (2002) states, "The notion that children could become potent witches was reinforced in postcolonial times by epidemics that mainly affected adults. An example of mimesis gone wrong, the belief in child sorcery is one of those unforeseen and tragic products of the colonial encounter" (p. 507).

Religion plays an important role in the life of many Amazonian indigenous peoples. In particular, Adventist and Evangelical missions have exerted and continue to exert significant influence among the Ashaninka (Rojas, 2014), even though in the country as a whole, approximately $76 \%$ of the population over the age of 12 identify as Catholic (Peru. National Statistics Institute, 2018) ${ }^{3}$.

Adventist missionaries arrived in the central rainforest region around 1920 (La Serna, 2011) and, among other things, promoted accusations of witchcraft. Many Ashaninka sought affiliation with the Adventist church, which resulted in the emergence of a complex syncretism of modern and traditional concepts to explain the presence of evil in the world.

Finally, it is important to highlight that in the Ashaninka belief system, child "sorcerers" are assumed to be under the influence of malignant beings (kamari), who have distorted their human nature and endowed them with magical powers along with an increased tolerance for pain and death. This is why they are punished or executed so cruelly (Santos-Granero, 2002, 2004).

\section{Theoretical Framework. Psychological Process and Sorcery}

Psychological research has shown that cultural arrangements frame moral life, but do not determine it. People in all cultural contexts participate in multifaceted social interactions and experience moral dilemmas and conflicts regarding matters of justice, social roles, power relations, and individual and group goals. Regardless of cultural background, all human individuals experience moral concerns and develop their own points of view about social and cultural matters, displaying critical thinking and dissident judgments and beliefs, as well as moral reasoning about their own culture (Frisancho \& Delgado, 2014, 2017; Turiel, 1997, 1998, 2002, 2006, 2012a, 2012b).

This study is framed by Piaget's (1970) and Kohlberg's (1963/2008, 1984) general ideas about development as ultimately governed by rationality, rather than by views of morality as a set of mainly emotional or automatic processes (Gigerenzer, 2007/2018; Haidt, 2001; Narvaez, 2014, 2016, 2018; Prinz, 2006, 2007, 2011). Such processes certainly occur and must be acknowledged, but are insufficient to fully account for the foundations of the moral phenomenon, and for its complexities in situations like the burning of witches. As Nucci (2016) has pointed out, "it is only through the use of reasoning that we can ever hope to generate moral perspectives that correct for the existing immorality in our social systems, or anticipate and respond to unforeseen moral problems" (p. 299).

\footnotetext{
3 The Seventh-day Adventist Church is a Protestant Christian movement that emphasizes the second coming (advent) of Jesus Christ, and the observation of rest on Saturday. Being missionary, the Adventist Church requires that their members comply with strict rules for life, including, in addition to the Commandments, significant dietary restrictions (La Serna, 2009). Evangelical missionaries, in turn, have worked extensively with Amazonian indigenous peoples through the Summer Institute of Linguistics (SIL), which focuses simultaneously on religious proselytizing, linguistics research, and teacher training. Although the SIL project was primarily religious in its origin, later negotiations with the organization and States in the region led it to incorporate the other two dimensions (Espinosa, 2018).
} 
In this vein, we understand development as an adaptive process and believe that children, adolescents, and adults actively construct the meaning of the world. From this perspective, development is rooted in the full range of cultural activities in which people engage (Piaget, 1966), and consists in the assimilation of new ideas and events into existing schemas, and the subsequent accommodation of those schemas to the new materials being assimilated (Piaget, 1952). Assimilation and accommodation are inseparable from each other.

We assume that human beings grow beyond the superficial in moral judgment as they go from regarding rules as obligatory, inviolable, and determined by the social group or authority, to a mature moral understanding of how the law and principles of justice interrelate. This means understanding the validity of principles as independent from both the group's authority and the individual's own identification or affective bonds with it (Kohlberg, 1984). Of course, social interaction is essential for moral development, and this interaction varies among cultures. Piaget (Piaget, 1932/1984, 1965/1995) wrote about morality as an interplay between individual cognitive and affective structures and the demands of social life, addressing topics such as the interrelation between individual, society, and rational knowledge from a developmental perspective. Kohlberg (Colby \& Kohlberg, 1987; Kohlberg, 1963/2008) has also shown that human moral reasoning requires an extensive background of cognitive growth and social experience, as it emerges from a person's interaction "with his or her social environment, rather than directly reflecting external structures given by the child's culture" (Kohlberg, 1963/2008, p. 19). This means that in every culture, an individual's capacity to reason and make judgments that balance different concerns and principles is always present. This capacity is shared by all human beings, regardless of culture. The ability to think and reason, which they call kenkeshirentsi, is constitutive of the Ashaninka notion of personhood (Rojas, 2014). Far from any "differentialist bias" (Dervin, 2016, as cited in Simpson \& Dervin, 2019, p. 3), constructivist approaches to moral development allow us to understand the articulation between shared capacities and diverse cultural practices. In other words, they make it possible to regard people whose cultural background differs from our own as both similar to and different from us. The recognition of the other implies taking both aspects into account.

Wainryb \& Recchia (2014), Wainryb \& Turiel (1993), and Wainryb (1991) have shown that informational assumptions (ideas about how the world works) are a source of variation in moral judgment. Individuals treat informational assumptions as facts and believe that the information they have about the world is true and credible even when it lacks scientific support. For instance, the Shipibo-Konibo, a Panoan-speaking Amazonian indigenous group, believe that the cosmic serpent, the great anaconda called Ronin, a magical creature described as the "mother of all boas", created the universe and is an emblem of rebirth, as it indicates the way humans must follow to return to earth after death. Ronin is believed to be tightly coiled around the four corners of the universe (Morales \& Mujica, 2019). This informational assumption makes the Shipibo-Konibo deeply respectful of the environments in which Ronin dwells and careful in their interactions with them. People from all cultural backgrounds develop moral judgments autonomously but bring their experiences and cultural beliefs to bear in their reasoning (Wainryb, 1991). They also balance different goals, values, and concerns as they critically evaluate the ways individuals relate to each other, analyze their cultural traditions, and make judgments based on moral principles (Helwig, 2006; Nucci \& Turiel, 2000; Turiel, 2006, 2012a; Wainryb, 2006; Wainryb \& Recchia, 2014).

For instance, belief in witchcraft is widespread among the Ashaninka; they believe that some individuals, especially children, "lose their human nature and become demonic witches" (Santos-Granero, 2004, p. 275). That it is possible under special circumstances for a human being 
to lose their humanity and become evil is an indisputable factual truth for the Ashaninka people: an "informational assumption".

Because the Ashaninka believe witches exist and cause many maladies, they try to eliminate them. This is the why children accused of sorcery are or punished severely, disappeared, or killed. It is a clear example of what Bandura (2002) calls a "mechanism of moral disengagement", a psychological maneuver that allow individuals to distance themselves from morally reprehensible actions and inhumane behaviors. Specifically, it is an example of dehumanization, a mechanism of moral disengagement that operates by devaluing an individual's humanity and blaming them for their own punishment. This cognitive mechanism has deep cultural roots among the Ashaninka.

\section{Method}

This research study is descriptive-interpretative. It focuses on the description and understanding of individual beliefs and ways of reasoning about social situations, moral conflicts and moral dilemmas (Colby \& Kohlberg, 1987; Goetz \& LeCompte, 1984; Valles, 1999). We used a qualitative semi structured theory-based interview, created for this study in order to explore participants' beliefs in witchcraft, their experience with witchcraft accusations, the dilemmas and conflicts they identify in connection with this cultural practice, and their moral reasoning about these dilemmas. In accordance with the study's objectives, participants' responses were analyzed from a constructivist perspective.

\section{Participants}

Six Ashaninka leaders participated in this research. Relying on our own judgment and knowledge of Ashaninka culture, we used purposeful sampling (Patton, 2015) to select the participants. Using typical case sampling, with the cooperation of key informants, we selected six Ashaninka leaders who, like all Ashaninka, have direct experience with witchcraft. In addition to their knowledge and cultural experience, we took into account their willingness to participate, as well as their ability to convey in a clear and reflective manner. It is important to note that, witchcraft being a very sensitive issue, it is not easy to find indigenous informants willing to share this aspect of their culture with strangers. Assuming as they do that witchcraft is real and dangerous, they fear the negative consequences of disclosing this information (for instance, being killed by their neighbors). As large amounts of useable data were obtained from each participant, and given the difficulty of finding informants, we decided six participants were enough for the purpose of this study. Their main characteristics are presented in the following table:

\section{Table 1}

Characteristics of the Study Participants

\begin{tabular}{lcccc}
\hline Participant & Gender & Age & $\begin{array}{c}\text { Degree of } \\
\text { instruction }\end{array}$ & $\begin{array}{c}\text { Place of } \\
\text { residence }\end{array}$ \\
\hline Ruth Buendía & Female & 40 & $\begin{array}{c}\text { Incomplete university } \\
\text { studies (law) }\end{array}$ & Lima \\
Victoria Mendoza & Female & Est. 85 & $\begin{array}{c}\text { First grade, } \\
\text { elementary school }\end{array}$ & Pucallpa
\end{tabular}




\begin{tabular}{lcccc} 
Magaly Perez & Female & 62 & $\begin{array}{c}\text { Complete technical } \\
\text { studies (nursing) }\end{array}$ & Pucallpa \\
Raúl Casanto & Male & 64 & $\begin{array}{c}\text { Incomplete high } \\
\text { school studies }\end{array}$ & Yurúa \\
Hilder Pérez & Male & 51 & $\begin{array}{c}\text { Complete high school } \\
\text { studies }\end{array}$ & Pucallpa \\
Benigno Vicente & Male & 39 & $\begin{array}{c}\text { Complete higher } \\
\text { education (pedagogy) }\end{array}$ & Pucallpa \\
\hline
\end{tabular}

\section{Instruments and Procedure}

The main objective of this study was to identify the moral dimension of Ashaninka leaders' reasoning about accusations of sorcery. To reach this goal and taking into account that the cultural differences between interviewers and interviewees require a flexible approach to achieve mutual understanding, semi-structured in-depth interviews were conducted. We specifically explored their experiences with witchcraft, their moral reasoning about the burning of witches, and their assessments of the righteousness of punishments used to control witchcraft.

All interviews were recorded. Informed consent was obtained for participation and the publication of the participants' names in this article, something that the participants themselves wanted and requested. Regarding informed consent, it should be noted that our previous research with Amazonian indigenous peoples, as well as the critical intercultural framework we adopt, led us to raise the need to challenge and adapt conventional procedures for informed consent (Frisancho, Delgado \& Lam, 2015). For the participants in this study, this has meant that informed consent was not limited to their initial acceptance of the interview but, given its procedural nature, involved taking it up in different ways throughout it. It also meant talking with the interviewees about the history and struggles of their people. We have had the opportunity to discuss these aspects in Ethics Committees and academic events.

With the exception of Victoria Mendoza's interview, which was conducted in Ashaninka with Hilder Perez and Benigno Vicente as translators, all the other interviews were conducted in Spanish. Data was analyzed using qualitative analysis to make inferences regarding participants' moral reasoning. Following Kohlberg's general idea of moral growth (Kohlberg, 1963/2008), we identified in the participants' discourse core statements about moral issues related to the practice of witchcraft.

\section{Results}

We report the study's results regarding the participants' moral reasoning about the violent punishment of accused witches in the following sequence: first, we present participant's ideas about the morality of punishments for sorcery. Second, we explore the ontological status of the sorcerer and how this cultural assumption relates to the practice of burning witches. Next, we present some qualitative data regarding the status of the practice of burning witches as a self-defense mechanism. Finally, we explore participants' search for universal justice within their own cultural context. In 
order to reproduce our interviewees' speech as accurately as possible, including non-standard usages and grammatical variances, we have approximated in translation the oral characteristics of their transcribed statements.

\section{Belief in Witchcraft and in the Punishment of Witches}

All participants believe in the existence of witches. "I am absolutely certain that sorcery and witchcraft exist. I am positive about it," says Raúl Casanto. And Hilder Pérez explains:

Sorcerers and witches do exist. They do evil things through the owl, who has a bad spirit. My mother told me that in the old times, when she was a child, the Ashaninka burned witches. The owl has an evil spirit and teaches wickedness, bad things. There are people who have the power of the owl; a bad spirit, a satanic spirit, gives them this power. At night the owl comes, it makes me use my food, my clothes, and then it buries it with evil intentions, to do bad things to me, a headache, a stomachache. It also fools you and adds herbs to your food, or puts herbs in your eyes, so you are transformed into a sorcerer.

Ruth Buendía tells how the sorcerer is attached to evil, kamari:

In Ashaninka culture, we have the myth of sorcery . . . the sorcerer is a person, but spiritually it is linked to kamari, or to insects like grasshoppers, which for us are evil. I am not against it, it is true, I believe sorcery exists.

Benigno Vicente points out that "witchcraft exists and can do much harm. That's why the Ashaninka used to kill the sorcerer, he could be killed with an arrow, with a stick, or by burning". He adds:

My father was a double orphan, he lost both parents and was raised by my grandmother ${ }^{4}$. He was accused of being a sorcerer. In Ashaninka culture, orphans were considered witches. That's why he had so many problems. Every adult, every child who got sick, they said: Eduardo Vicente [Benigno's father] is to blame. The witch in my community was my neighbor. She killed two gentlemen. Her punishment was to carry the dead alone and to cultivate their farm.

Accusations of sorcery are highly rational within the Ashaninka belief system. As cultural practices often conflict with an individuals' autonomous judgment, however, there are dissenters in all societies, and the Ashaninka are no exception. For instance, asked about the killing of witches, Ruth Buendía says:

\footnotetext{
${ }^{4}$ Benigno refers in this way to the woman who sheltered and raised his father, not his father's biological mother, who had died.
} 
It worries me. In the community there are many problems, somebody says 'I am sick, I have been cursed, let's kill the witch'. And this is a problem for me... What could I say? We should not violate human rights. But my Ashaninka brothers and sisters do not understand, 2 or 3 years ago they killed an 18-year-old girl who had been abused twice, first she was raped when she was 12. We Ashaninka have sex at a very early age; she was abused maybe because of her own history, because of ignorance, because of illiteracy, but now in the Twenty-First century we must no longer allow this. I am a leader, I represent an indigenous organization, and I cannot allow this to happen. The person who killed her was a relative of mine, first degree of consanguinity, but I said I would tell the police anyway. For me -I said to him-you should go to jail because you cannot kill a person.

Then, she continues:

She was killed because people thought she was a witch. But I was sure she was not a witch; my opinion went against the opinion of the majority. So . . . What did they say to me? 'You have betrayed us, you are no longer Ashaninka, you have changed your ideas'. 'Chori ' they said, 'mestiza'. . . you are not Ashaninka anymore because you defend the witch.

Because she no longer accepts some traditional beliefs, Ruth faced rejection from her community. Educated in the logic of human rights, she radically opposes the practice of burning witches. The same is true of Raúl and Benigno. Raúl says:

I cannot approve of the killing of witches; I no longer approve of $i t$. These are modern times, there are valuable traditional practices that we have to salvage, but there are others we need to get rid of.

On his part, Benigno explains:

I think that's wrong. Every being who breathes on Earth has the right to life, no matter what. We must have the opportunity to learn, we all have the right to improve and change, and that is not going to be achieved by killing. Moreover, if you kill a sorcerer, another one appears, and nothing is solved. In the old times, my fellow countrymen did not know that people have rights, at that time everything in the indigenous world was about killing and dying, the only way to solve a problem was by killing, but that is not correct. Since then, they have reflected, and those ideas have changed. Killing solves nothing. It brings about more conflicts, the victim's

\footnotetext{
${ }^{5}$ Among the Ashaninka, Chori is a common colloquial word for mestizo, a non-indigenous person of mixed race. It especially refers to people from the Andean region.
} 
family wants revenge and may kill your child, although he may not be a witch, and so on.

It is not that their level of educational attainment or their contact with Western culture have completely transformed the participant's belief system. On the contrary, they still believe in witchcraft as a natural phenomenon (see Hunter, 2012). However, human rights and Christianity are available to them now as frameworks for a critical analysis of the social conflicts that emerge around witchcraft. Religion plays an important role in Raúl Casanto's rejection of witch-killing. Raúl, who is Adventist, says:

Biblically speaking, crime is condemned, the law of God says "thou shall not kill”; so, I am against killing. Now... what can we do -this is the question - what can we do so this person stops being a witch and no longer harms others? On the one hand, we do not have anything written, but . . . How did we Ashaninka, without anything written, know that adultery is wrong? Lying is wrong, stealing is wrong. But... Who said that? That did not come from the Church, because in the time of the Inca they had the same laws. So, before that we already talked about right and wrong. For us, Pawa [the Ashaninka name for God] does exist, but beside him and all the good things he does, there is a Kamari who does the opposite. Human beings are between those two.

For Raúl, Benigno, and Ruth, sorcery is a social and human problem related to justice, to the well-being of people and their right to life. While holding on to their belief in the reality of witchcraft, they criticize traditional Ashaninka practices to control it as violations of fundamental human rights.

In turn, Magaly Pérez attributes her father's rejection of violence against sorcerers also to the influence of Adventist preachers. As a child, she witnessed her father, a schoolteacher and Adventist missionary, help a woman accused of witchcraft. Asked why, in her view, her father helped the accused witch, Magaly says:

Because the Adventist church also has rules against killing. The Ten Commandments say we shall not kill. We as indigenous peoples do not know God. As my mom says, what would our beliefs be if the Church had not arrived? We would be worshiping fire, the sun. But the Church arrived and the Bible says we shall not kill. That's why my father, as a good Christian, helped her. The Church teaches you about the Good Samaritan.

Victoria Mendoza, Magaly's mother, grew up without much contact with Western culture. "I was born before civilization arrived," is how she puts it. Victoria firmly believes in the existence of witches, and has witnessed violent actions against them. She thinks that the abandonment of such practices has to do with the Ashaninka increased interaction with the West, although she does not link it to human rights or religious commandments. She says:

Children were killed before but not anymore, because we have already experienced civilization. That is why people change, because now they 
have self-esteem. They did not have self-esteem in the past. Be it your own child or someone else's child, be it your mother or your siblings, you could kill. But when we entered civilization, you only ask, and then you normally cure the person.

As we can see, contact with foreign ideas has been important for participants to adopt a critical stance towards the punishment of accused witches, even as their belief in sorcery remains strong. It must nevertheless be noted that the questioning of traditional beliefs sometimes occurs within a framework of asymmetric, hierarchical intercultural relations, as can be seen in Victoria Mendoza's narrative.

\section{The Dehumanization of the Sorcerer}

One informational assumption that may favor violence against accused witches is their ontological status, that is, the degree of humanity that is attributed to them. It is one thing to think of the accused as a "normal human being" who does evil things, and another altogether to believe their "human nature" to have been made intrinsically evil.

The ontological status assigned to the witch can favor mechanisms of moral disengagement and the endorsing of violence. Mistreating people is much easier if they are not acknowledged as fully human. Note that attributions of humanity are culture-bound and do not coincide with Western uses of the category (see de Castro, 1998). Nevertheless, the psychological dynamics described by Bandura (2002) remain operative, and this study's interviews show that accused witches are subject to dehumanization. The study participants emphasize a "possession" or "intrusion" that radically affects a person's will and agency. Evil seizes people and turns them into witches.

Magaly Pérez points out that someone who is already a witch converts others, shifting their will towards evil ends:

When a spell is cast on a person, he feels like a tingling in his mouth and from then on, he starts to dream about whoever cast the spell on him, he hears that person in his dreams saying: "you have to go and kill Mr. so and so". Then he goes and becomes a little bird, he leaves already transformed and starts doing his work. People say they become animals.

In the same vein, Victoria Mendoza explains:

The sorcerer could be any person, a person like us or like those who are watching us now. But at night, when he sleeps, for the sorcerer we are no longer people. They see us as animals. That's why they curse us. Just as we like to kill animals, to eat deer, the same way the sorcerer sees us as his food.

Benigno Vicente emphasizes that it is the "allies", the "bad spirits" (kamari), who make a witch do evil. More than a radical ontological transformation, his story, like those of Magaly and Victoria, speaks of possession by a spirit that takes over and transforms the individual's free will and nature. Benigno explains: 
What makes a person bad are her allies, the kamari spirits. The bad spirit pushes her, it does so by dreams. My neighbor is still normal, she is still a good person but evil is so strong that, you know, she has to do bad things, she can't help it. There is a struggle between the evil spirits and the person.

Questioning the "informational assumption" about the nature of the witch - that is, seeing him as a human being and not as an animal or as someone possessed by evil- is essential to distance oneself from violent actions. Ruth Buendía is particularly clear about this. When people in her community decided to burn a witch and criticized Ruth for "taking the witch's side", she responded:

But this witch is a natural person, she has rights, she knows how to cry just like you do, she also suffers, and we do not have the right to take her life.

As a consequence of her recognition of the witch's moral standing, Ruth was rejected by her own family. "You are no longer my family," they said, a painful experience for her. It should be noted that Ruth's moral perspective-taking is particularly significant in the context of a collectivist culture. Balancing the demands of her community with her own moral thinking, Ruth says:

For me, as an Ashaninka, it is important to be close to and have bonds with my family, but being an authority and a leader, and knowing about human rights, I could not become complicit in that crime.

From the standpoint of intercultural education, our participants pose several challenges both for the Ashaninka and for people with other cultural affiliations. On the one hand, as shown by Ruth Buendía, emphasizing the humanity of an accused witch opens a path to questioning violent practices. On the other hand, to what extent can a "possessed" person be held responsible for their actions, real or attributed? Certainly, the existence of punishments implies that those identified as witches are still seen as culpable, even though evil is believed to have altered their nature. This justifies the violence to which they are subjected. Understanding this violence requires some additional clarifications, which we will discuss next.

\section{Homicide or Self-defense?}

An awareness of the cultural framework that sustains such practices as the execution of accused witches is required to understand their rationality. Although they express strong disagreement with the burning of witches, the participants' statements highlight two important issues. First, they believe that being a matsi changes a person's nature or will; if witches are no longer considered human or their humanity is seen as degraded, killing them is not a homicide in the strict sense. Second, the matsi are believed to possess "really existing" powers and the ability to cause harm; killing them, then, can be construed as an act of self-defense.

When Raúl Casanto was a child, he witnessed his grandmother defend a small girl who faced execution. Raúl explains that his grandmother was harshly criticized for this, since people believed that allowing the girl to live would mean supporting her future "crimes". Raúl says: 
When I was 6 or 7, I witnessed it. A girl was going to be burned, people accused her of being a witch. One day a woman came running, desperate, and said to my grandmother: "Comadre ${ }^{6}$, they are going to burn Mónica!'”. "Who is?". "A guy, Mr. so and so, he says he's gotten sick because of some witchcraft". And my grandmother said "Let's go see", and ran over there. When we arrived, the wood was already burning and the girl was tied down, and they were going to put her in that fire.

The girl's accuser had left, probably into the forest. People were waiting for him to return and give the order. Raúl's story continues:

My grandmother begged them not to kill the girl: "If she has done something wrong, please give her to me, I will raise her". But they did not want to. They said to my grandmother: "Look, if you want to take this witch, we'll kill you too. You are supporting people who kill other people. Look at the one who is sick here, he is about to die and it is because of this". My grandmother cried. I was very frightened watching everything. Then, suddenly, another guy came and said: "No, we are not going to kill her here". There were two tree trunks nearby that could be used as a raft; he grabbed them and tied the girl's feet and head, her hands, everything he tied to the trunks, and threw her into the Perené river. And the river took the girl.

The murder of the girl was construed by the community as an act of self-defense. The story highlights intracultural differences in the moral evaluation of a cultural practice.

\section{In Search for Justice: Reasoning Morally About Cultural Practices}

Reasoning morally about cultural practices without renouncing one's attachment to a given cultural identity requires adopting a dynamic concept of culture. Raúl strongly opposes the burning of human beings; for him, "in modern times" the Ashaninka need to critically analyze "our traditions, our ancestral practices and customs". Ruth points out:

Cultures change and must change; and it's not that I want to change to forget everything we have, on the contrary, we have to value those things that are good and improve them, renew them.

This way of reasoning involves questioning not only the violence inflicted on accused witches, but also the sheripiari's powers and infallibility. Raúl Casanto says:

\footnotetext{
${ }^{6}$ The word comadre literally means "co-mother", and indicates a relationship between the parents and godparents of a child. The word is sometimes used without any institutional relationship, just to mean a strong familiarity between individuals.
} 
The wise man or sheripiari is like a god to us, he knows how to interact with nature. But there is one thing I always criticize: this wise man, the sheripiari, often leads you to believe there are bad people, like sorcerers, who hurt you [...]

Both Ruth and Raúl think that a sheripiari can be wrong, and that their errors can lead to situations of injustice. To control this, Raúl proposes a sort of regulation to identify and punish witches:

I believe several sheripiaris should decide if a person is or is not a witch. One person alone should not have full power to decide. What happens if he is wrong? A sheripiari can be wrong, but if there are several sheripiaris thinking together it is more difficult to be wrong. Twenty days ago, in Pucallpa, the prosecutors called the indigenous leaders in to analyze special justice... they addressed the issue of how native communities do justice when a crime is perpetrated. There was a big debate. So, we agreed to set up a working group to produce a small manual for regulating the procedures that should be followed before executing a sorcerer, the steps we must follow, let's say.

In his quest for the establishment of justice as a universal value but based on his culture's informational assumptions (for instance, the belief that sheripiaris have special powers), Raúl Casanto proposes expert judging as a useful validation criterion. Benigno Vicente's story also shows how reasoning and a concern with universal values like justice can be articulated with specific cultural elements:

Sometimes people want to kill a witch but end up killing an innocent person, and that's very wrong. That's why in Ashaninka we say to the person who wants to kill 'Paminaperotatyero ñantsi', which means "you have to see well, think carefully, analyze things before proceeding”. Killing witches is incorrect because people are equal in rights, the personal self may be different, what we have learned in life is different, but we are equal in rights.

These vignettes help identify how a path towards universal principles can be constructed on the basis of reasoning, while remaining within the bounds of a particular culture. This has important consequences for moral education and intercultural dialogue.

\section{Conclusions: Morality and Intercultural Education}

This study used a typical case sampling. The results are not generalized statements about the experiences of all Ashaninka people or of every Ashaninka who exercises a leadership role. However, as the participants are typical Ashaninka individuals, the results function as counterweight for the common psychological misconception that indigenous peoples do not reason morally in the same way as Westerners do. This study allows us to draw three main conclusions: 
First, our research shows that moral reasoning does not require jettisoning one's own culture-bound informational assumptions. The six interviewees strongly believe in the existence of witches and the reality of witchcraft; at the same time, albeit to varying degrees, they are able to reason morally about the mechanisms used by their communities to control and punish witches. Thus, this study contributes to the literature exploring the diversity of moral perspectives that coexist within a given culture (Killen et al., 2015; Turiel, 2012a; Wainryb, 2006).

Second, our research makes visible the universal-justice dimensions of non-Western cultures. Indigenous Amazonian peoples in general, and the Ashaninka leaders in particular, are deeply concerned with justice and analyze their own cultural practices critically through moral lenses. As the vignettes presented in this paper show, our study's participants see the cultural practice of burning witches through moral lenses; their moral reasoning shows up, in varying degrees, in a preoccupation with the witches' humanity and human status, a concern with the proportionality of the punishments and the right of the accused to improve and change, and a search for agreement between judges in the interest of fairness and due process. These concerns are shared by justice systems all over the world, and are included in The Universal Declaration of Human Rights (General Assembly of the United Nations, 1948) and other multilateral treaties, such as the International Covenant on Civic and Political Rights (Office of the High Commissioner for Human Rights, 1966) and the American Convention on Human Rights (Organization of American States (OAS), 1969). This contradicts both a relativistic understanding of morality, and a common-sense view that posits indigenous cultures as incommensurable with the West and ethical principles as an exclusively Western construction.

Third, there are many different cultural paths towards universal moral principles, people who believe in witches can at the same be aware of human rights and attempt to reconcile their cultural beliefs and practices with a view of punishment and justice balanced by the latter. This indicates that some universalism is compatible with an attention to the particularities of specific cultures, as other studies have shown (Frisancho \& Delgado, 2014, 2017; Greenfield et al., 2003; Piaget, 1964/1985).

From an academic perspective, it is important to raise these topics in order to foster a better understanding of indigenous people's rationality, and to build a fruitful dialogue between universals and particulars. Intercultural education must embed the moral dimension with a critical framework, which means questioning the naturalization of asymmetric cultural judgments (as when certain beliefs are labeled "religion", and therefore deemed respectable, while others are seen as superstitions to be eradicated.) As Gorski (2008) has stated, despite the good intentions of intercultural educators, the actual practice of intercultural education tends to support existing hegemonies, privileges, and social hierarchies. Moreover, people in Peru, including teachers and students, are all too often negatively biased towards Amazonian indigenous peoples, seeing them as violent, morally inferior, and "innately savage" (Espinosa, 2009, 2012, 2017; La Serna, 2011; Vigil, 2010). Set against this tradition of longstanding prejudice, our research contributes to the dismantling of negative images by illuminating the sophistication of Ashaninka moral reasoning. Intercultural educators from anywhere in the world will find this idea a powerful one: that regardless of their cultural background, a human person is always in possession of agency and capable of reflective processes.

Understanding the rationality behind events such as the burning of witches, which at first glance may seem to validate the prejudice of Amazonian Indians as "savages", allows nonindigenous observers to accommodate the schemas deployed for the understanding and 
assimilation of the other. In this way, we can avoid the distorting assimilation (Piaget, 1952, 1970) that takes place when the complexity of the object of knowledge exceeds that of the schema to which this object refers, or when the complexity of a given reality is greater than that of the schemas that represent it. Distorting assimilation makes a person unable to abandon his or her own egocentric point of view and to fully understand the other; rather than accommodating schemas to assimilate reality, distorting assimilation integrates reality to a person's existing point of view, thus transforming it into a function of personal perceptions and affectivity. By countering this process, our study contributes to a better understanding or the other as a rational and moral agent, and helps clear a pathway towards true intercultural recognition and cooperation.

In consequence, we conclude that intercultural education needs to include moral education (Frisancho \& Delgado, 2018), but a kind of moral education that rejects reductionism and gives centrality to reason (Kohlberg, 1966; Lerner, 2015; Nucci, 2016). As Benigno Vicente put it in his native Ashaninka, what is needed is paminaperotatyero ñantsi: "to see clearly, to think carefully, to analyze things before proceeding". The automatic intuitive-emotional processing that some authors propose as central to morality (Gigerenzer, 2007/2018; Haidt, 2001; Narvaez, 2014, 2016, 2018; Prinz, 2006, 2007, 2011) are not sufficient to understand the complexities of a different culture, to comprehend the rationality of others, or to critically analyze the informational assumptions that operate in one's own culture.

As indigenous peoples are incorporated into capitalist globalization at an accelerating rate, and as indigenous and mestizo populations come into increased contact, different cultural practices that may violate the human rights of either or both groups also begin to coexist. In this context, moral education must necessarily be intercultural in character and include the exploration of conflicts and moral dilemmas encountered by indigenous leaders, like those we have discussed.

Finally, since "witchcraft appears as the daughter of misery" (Chauvelot, 1995/2001, p. 61), attention must be paid to the structural conditions in which intercultural relations take place. Intercultural education must discuss the specific ways in which indigenous groups are impacted by the inequities of a globalized society, and the causes of such inequities. Following Nucci (2016) we believe that the pedagogical discussion of an issue as complex as the burning of witches cannot be accomplished without promoting a critical view of social inequalities, both within and between cultures.

\section{References}

Aguilar, J. (2005). The invention of child witches in the Democratic Republic of Congo. Social cleansing, religious commerce and the difficulties of being a parent in an urban culture. Save the Children.

Associated Press. (2016, September 28). Woman burned as a witch in Peruvian rainforest, prosecutor says. The Guardian. https://www.theguardian.com/world/2016/sep/28/womanburned-witch-peru-rainforest-prosecutor

Bandura, A. (2002). Selective moral disengagement in the exercise of moral agency. Journal of Moral Education, 31(2), 101-118. https://doi.org/10.1080/0305724022014322

Baral, S. (2014, November 4). Adolfina Ocampos, accused of witchcraft in Paraguay, is burned alive and shot with arrows. Latin Times. https://www.latintimes.com/adolfina-ocamposaccused-witchcraft-paraguay-burned-alive-and-shot-arrows-273973

Chauvelot, D. (2001). Historia de la histeria. Alianza Editorial. J.M. Marinas, Trad. (Original work 
published 1995).

Colby, A., \& Kohlberg, L. (1987). The measurement of moral judgment: Volume 1: Theoretical foundations and research validation. Cambridge University Press.

Comisión de la Verdad y Reconciliación. (2003). Informe final. http://cverdad.org.pe/ifinal/

Csordas, T. J. (2013). Morality as a cultural system? Current Anthropology, 54(5), 546. https://doi.org/10.1086/672210

Davidson, H. (2018, January 4). "Bloodlust hysteria": Sorcery accusations a brutal death sentence in Papua New Guinea. The Guardian. https://www.theguardian.com/world/2018/jan/05/bloodlust-hysteria-sorcery-accusationsa-brutal-death-sentence-in-png

de Castro, E. V. (1998). Cosmological deixis and Amerindian perspectivism. The Journal of the Royal Anthropological Institute, 4(3), 469. https://doi.org/10.2307/3034157

Erikson, P. (2016). Si matamos a un Brasileño, ¿En qué le concierne al gobierno? Análisis de un caso de brujería entre los Chácobos. In A. Surrallés, O. Espinosa, \& D. Jabin (Eds.), Apus, caciques y presidentes: Estado y política indígena amazónica en los países andinos (pp. 179-194). IWGIA.

Espinosa, O. (2003). Desafíos a la ciudadanía multicultural en el Perú: El "mito del mestizaje" y la "cuestión indígena." In N. Vigil \& R. Zariguiey (Eds.), Ciudadanias inconclusas. El ejercicio de los derechos en sociedades asimétricas (pp. 77-89). Cooperación Técnica Alemana (GTZ) and Pontificia Universidad Católica del Perú.

Espinosa, O. (2009). ¿Salvajes opuestos al progreso?: Aproximaciones históricas y antropológicas a las movilizaciones indígenas en la Amazonía Peruana. Anthropologica, 27(27), 123-168. http://www.scielo.org.pe/pdf/anthro/v27n27/a07v27n27.pdf

Espinosa, O. (2012). La violencia y la historia asháninka: de Juan Santos Atahualpa a Sendero Luminoso. In J. P. Chaumeil, F. Correa, \& R. Pineda (Eds.), El aliento de la memoria: Antropología e historia en la Amazonia andina (pp. 283-301). IFEA, Universidad Nacional de Colombia.

Espinosa, O. (2017). La educación superior intercultural en la Amazonía Peruana: Balance y desafíos. Anthropologica, 35(39), 99-122. https://doi.org/10.18800/anthropologica.201702.005

Espinosa, O. (2018). La relación de la Iglesia católica y las Iglesias evangélicas con las organizaciones indígenas en la Amazonía Peruana: La experiencia del pueblo achuar. Http://Journals.Openedition.Org/Bifea, 47(3), 267-292. https://doi.org/10.4000/bifea.10226

Frisancho, S. \& Delgado, G.E. 2014. Razonamiento sobre Derechos Humanos y Prácticas Culturales en Tres Adultos de Comunidades Indígenas del Perú. Schème, Revista Eletrônica de Psicologia e Epistemologia Genética 6, 141-163. https://doi.org/10.36311/19841655.2014.v6n0.p141-163

Frisancho, S., Delgado, G.E. \& Lam, L. 2015. El consentimiento informado en contextos de diversidad cultural. Limite 10, 3-12.

Frisancho, S. \& Delgado, G.E. 2017. La Ética del Chamanismo: Conflictos Morales de Chamanes de los Pueblos Ashaninka y Shipibo-Konibo por el Uso del Dinero. Schème, Revista Eletrônica de Psicologia e Epistemologia 9, 290-319. https://doi.org/10.36311/19841655.2017.v9esp.11.p290 
Frisancho, S. \& Delgado, G.E. 2018. Moral Education as Intercultural Moral Education. Intercultural Education 29 (1), 18-39. https://doi.org/10.1080/14675986.2017.1405214

Garra, S. (2016). Entre la Brujería y la Ley: Los certificados de un Iwishin Awajún. In A. Surrallés, O. Espinosa, \& D. Jabin (Eds.), Apus, caciques y presidentes: Estado y política indígena amazónica en los países andinos (pp. 195-213). IWGIA.

General Assembly of the United Nations. (1948). Universal Declaration of Human Rights. https://www.un.org/en/universal-declaration-human-rights/

Gigerenzer, G. (2018). Decisiones instintivas. La inteligencia del inconsciente. Ariel. J. Soler Chic, Trad. (Original work published 2007).

Goetz, J., \& LeCompte, M. (1984). Ethnography and qualitative design in educational research. Academic Press.

Gorski, P. (2008). Good intentions are not enough: A decolonizing intercultural Education. Intercultural Education, 19(6), 515-525. https://doi.org/10.1080/14675980802568319

Greenfield, P. M., Keller, H., Fuligni, A., \& Maynard, A. (2003). Cultural pathways through universal development. Annual Review of Psychology, 54, 461-490. https://doi.org/10.1146/annurev.psych.54.101601.145221

Haidt, J. (2001). The emotional dog and its rational tail: A social intuitionist approach to moral judgment. Psychological Review, 108(4), 814-834. https://doi.org/10.1037/0033295X.108.4.814

Helwig, C. C. (2006). Rights, civil liberties, and democracy across cultures. In M. Killen \& J. G. Smetana (Eds.), Handbook of moral development (pp. 185-210). Lawrence Erlbaum Associates Publishers. https://psycnet.apa.org/record/2005-11748-007

Hermkens, A. K. (2015). The gendered politics of witchcraft and sorcery accusations among the Maisin of Papua New Guinea. Asia Pacific Journal of Anthropology, 16(1), 36-54. https://doi.org/10.1080/14442213.2014.986191

Humanist International. (2020, April 24). “Alleged witches are still killed today, in 2020”, says humanist anti-witchcraft activist Leo Igwe. [Press release]. https://humanists.international/2020/04/alleged-witches-are-still-killed-today-in-2020says-humanist-anti-witchcraft-activist-leo-igwe/?lang=es

Hunter, J. (Ed.). (2012). Paranthropology: Anthropological approaches to the paranormal. Lulu.

Jamieson, M. (2008). Sorcery, ghostly attack, and the presence and absence of shamans among the Ulwa and Miskitu of eastern Nicaragua. Journal of the Royal Anthropological Institute, 14(3), 554-571. https://doi.org/10.1111/j.1467-9655.2008.00517.x

Killen, M., Hitti, A., Cooley, S., \& Elenbaas, L. (2015). Morality, Development, and Culture. In M. Gelfand, C. Y. Chiu, \& Y. Y. Hong (Eds.), Advances in Culture and Psychology (pp. 161-220). Oxford University Press.

Kohlberg, L. (1963/2008). The development of children's orientations toward a moral order. Human Development, 51(1), 8-20. https://doi.org/10.1159/000112530

Kohlberg, L. (1966). Moral education in the schools: A developmental view. The School Review, 74(1), 1-30. https://doi.org/10.1086/442759

Kohlberg, L. (1984). Essays on moral development. Vol 2: The psychology of moral development. Harper \& Row.

Kowal, E., \& Paradies, Y. (2005). Ambivalent helpers and unhealthy choices: Public health practitioners' narratives of Indigenous ill-health. Social Science and Medicine, 60(6), 1347-1357. https://doi.org/10.1016/j.socscimed.2004.07.009

La Serna, J. C. (2009). Más allá de la parusía: El enfrentamiento al demonio en el bosque: 
Religión, política y sociedad asháninka a través de la presencia misionera adventista en la selva central Peruana (1920-1990). Universidad Nacional Mayor de San Marcos.

La Serna, J. C. (2011). Viviendo con el diablo en casa. La enfermedad, hechicería infantil y violencia entre los asháninka desde la perspectiva misionera adventista. Bulletin de l'Institut Français d'études Andines, 40(1), 81-121. https://doi.org/10.4000/bifea.1580

Lallanilla, M. (2013, June 7). Witchcraft accusations lead to torture, murders $\mid$ Live science. Live Science. https://www.livescience.com/37281-witchcraft-accusations-murder-witch-huntssorcery.html

Lerner, R. M. (2015). Promoting social justice by rejecting genetic reductionism: A challenge for developmental science. Human Development, 58, 67-69. https://doi.org/10.1159/000381273

Makoye, K. (2017, August 22). Tanzania charges mob with killing, burning five "witches." Reuters. https://uk.reuters.com/article/us-tanzania-crime-witchcraft/tanzania-chargesmob-with-killing-burning-five-witches-idUSKCN1B2208

Morales, D., \& Mujica, A. (2019). La arqueología y el mito de origen de los shipibo-conibo de la Amazonía Peruana. Investigaciones Sociales, 22(40), 85-96. https://doi.org/10.15381/is.v22i40.15888

Müller, C., \& Sanderson, S. (2020, August 10). Witch hunts: A global problem in the 21st century. Deutsche Welle. https://www.dw.com/en/witch-hunts-a-global-problem-in-the-21stcentury/a-54495289

Narvaez, D. (2014). Neurobiology and the development of human morality: Evolution, culture, and wisdom. Norton Professional books.

Narvaez, D. (2016). Embodied morality: Protectionism, engagement and imagination. In Embodied morality: Protectionism, engagement and imagination. Palgrave Macmillan. https://doi.org/10.1057/978-1-137-55399-7

Narvaez, D. (Ed.). (2018). Basic needs, wellbeing and morality: Fulfilling human potential. Palgrave Macmillian. https://doi.org/10.1007/978-3-319-97734-8

Nucci, L. (2016). Recovering the role of reasoning in moral education to address inequity and social justice. Journal of Moral Education, 45(3), 291-307. https://doi.org/10.1080/03057240.2016.1167027

Nucci, L., \& Turiel, E. (2000). The moral and the personal. Sources of social conflict. In L. Nucci, G. B. Saxe, \& E. Turiel (Eds.), Culture, thought, and development. Lawrence Earlbaum. https://doi.org/10.4324/9781410603470

Office of the High Commissioner for Human Rights. (1966). International covenant on civil and political rights. In Treaty series, Vol. 999 (p. 171). https://www.ohchr.org/en/professionalinterest/pages/ccpr.aspx

Organization of American States. (1969). American convention on human rights, "Pact of San Jose”, Costa Rica. https://www.cidh.oas.org/basicos/english/basic3.american convention.htm

Patton, M. Q. (2015). Qualitative research \& evaluation methods: Integrating theory and practice. Sage.

Peru. Ministry of Culture. (2020). Lista completa de pueblos indígenas u originarios. https://bdpi.cultura.gob.pe/sites/default/files/archivos/paginas_internas/descargas/Lista de Pueblos Indígenas u Originarios 24112020.pdf

Peru. Ministry of Education. (2013). Hacia una educación intercultural bilingüe de calidad. 
Propuesta pedagógica. http://www.minedu.gob.pe/minedu/archivos/a/002/01-general/2propuesta_pedaggogica_eib_2013.pdf

Peru. Ministry of Education. (2016). Currículo nacional de la educación básica. http://www.minedu.gob.pe/curriculo/pdf/curriculo-nacional-2016-2.pdf

Peru. National Statistics Institute. (2018). Resultados definitivos. Tomo I.

Piaget, J. (1932/1984). El criterio moral en el niño. Martínez Roca.

Piaget, J. (1952). The origin of intelligence in children. International Universities Press.

Piaget, J. (1964/1985). Seis estudios de psicología. Planeta.

Piaget, J. (1965/1995). Sociological studies. Routledge.

Piaget, J. (1966). Need and significance of cross-cultural studies in genetic psychology. In J. W. Berry \& P. R. Dasen (1974) (Eds.), Culture and cognition: Readings in cross-cultural psychology. Routledge.

Piaget, J. (1970). Piaget's theory. In P. H. Mussen (Ed.), Carmichael's handbook of child psychology (pp. 703-732). John Wiley \& Sons.

Portocarrero, G. (2007). Racismo y mestizaje y otros ensayos. Fondo Editorial del Congreso del Perú.

Prinz, J. (2006). The emotional basis of moral judgments. Philosophical Explorations, 9(1), 2943. https://doi.org/10.1080/13869790500492466

Prinz, J. (2007). The emotional construction of morals. Oxford University Press.

Prinz, J. (2011). The death of morality. Morality is a culturally conditioned response. Philosophy Now,

82. https://philosophynow.org/issues/82/Morality_is_a_Culturally_Conditioned_Response

Rojas, E. (1994). Los Ashaninka, un pueblo tras el bosque. Fondo Editorial de la Pontificia Universidad Católica del Perú.

Rojas, E. (2014). El morral del colibrí. Mitología, chamanismo y ecología simbólica entre los ASHANINKA del Oriente Peruano. Horizonte.

Sani, S. (2015). The importance of intercultural education in developmental age. Procedia - Social \& Behavioral Sciences, 197(25), 1148-1151. https://doi.org/10.1016/j.sbspro.2015.07.369

Santos-Granero, F. (2002). Saint Christopher in the Amazon: Child sorcery, colonialism, and violence among the Southern Arawak. Ethnohistory, 49(3), 507-543. https://doi.org/10.1215/00141801-49-3-507

Santos-Granero, F. (2004). The enemy within: Child sorcery, revolution, and the evils of modernization in Eastern Peru. In N. L. Whitehead \& R. Wright (Eds.), In darkness and secrecy: The anthropology of assault sorcery and witchcraft in Amazonia (pp. 272-305). Duke University Press. https://doi.org/10.1215/9780822385837-012

Schmidt, S. (2017, March 1). 'She was demonized': Nicaraguan woman dies after being thrown into fire in exorcism ritual. The Washington Post. https://www.washingtonpost.com/news/morning-mix/wp/2017/03/01/she-wasdemonized-nicaraguan-woman-dies-after-being-thrown-into-fire-in-exorcism-ritual/

Simpson, A., \& Dervin, F. (2019). Global and intercultural competences for whom? By whom? For what purpose? : An example from the Asia Society and the OECD. Compare: A Journal of Comparative \& International Education, 49(4), 672-677. https://doi.org/10.1080/03057925.2019.1586194

Sueyo, A., \& Sueyo, H. (2017). Soy Sontone. Memorias de una vida en aislamiento. IEP y Ministerio de Cultura.

Tubino, F. (2015). La interculturalidad en cuestión. Pontificia Universidad Católica de Perú. 
Journal of Ethnic and Cultural Studies

Copyright 2021

2021, Vol. 8, No. 2, 1-20

ISSN: 2149-1291

http://dx.doi.org/10.29333/ejecs/532

https://dialnet.unirioja.es/servlet/articulo?codigo $=6512628$

Turiel, E. (1997). Beyond particular and universal ways: Contexts for morality. New Directions for Child \& Adolescent Development, 1997(76), 87-105. https://doi.org/10.1002/cd.23219977608

Turiel, E. (1998). Notes from the underground: Culture, conflict, and subversion. In J. Langer \& M. Killen (Eds.), Piaget, evolution, and development (pp. 271-296). Lawrence Erlbaum Associates.

Turiel, E. (2002). The culture of morality. In The culture of morality: Social development, context, and conflict. Cambridge University Press. https://doi.org/10.1017/cbo9780511613500

Turiel, E. (2006). Thought, emotions, and social interactional processes in moral development. In M. Killen \& J. G. Smetana (Eds.), Handbook of moral development (pp. 7-35). Lawrence Erlbaum Associates Publishers. https://psycnet.apa.org/record/2005-11748-001

Turiel, E. (2012a). Moral reasoning, cultural practices, and social inequalities. Innovación Educativa, 12(59), 17-32. https://dialnet.unirioja.es/servlet/articulo?codigo=4165106\&info=resumen\&idioma=ENG

Turiel, E. (2012b). Moral universality and relativism: Variations in social decisions, social opposition and coordination as bases for cultural commonalities. In J. García, R. Kohen, C. del Barrio, I. Enesco, \& J. Linaza (Eds.), Construyendo mentes. Ensayos en homenaje a Juan Delval. UNED.

United Nations Educational, Scientific and Cultural Organization. (2006). Directrices de la UNESCO la sobre educación intercultural. https://unesdoc.unesco.org/ark:/48223/pf0000147878_spa

Valles, M. S. (1999). Técnicas cualitativas de investigación social: Reflexión metodológica y práctica profesional. Síntesis.

Vigil, N. (2010). Racismo en el discurso sobre los asháninkas de Satipo. Discurso \& Sociedad, 4(3), 538-578. www.dissoc.org

von Dacre, J. S. (2019, June 19). Thousands killed in Tanzania for being witches. Inside Over. https://www.insideover.com/society/thousands-killed-in-tanzania-for-being-witches.html

Wainryb, C. (1991). Understanding differences in moral judgments: The role of informational assumptions. Child Development, 62(4), 840-851. https://doi.org/10.2307/1131181

Wainryb, C. (2006). Moral development in culture: Diversity, tolerance, and justice. In M. Killen \& J. G. Smetana (Eds.), Handbook of moral development (pp. 211-240). Lawrence Erlbaum Associates Publishers. https://psycnet.apa.org/record/2005-11748-008

Wainryb, C., \& Recchia, H. (2014). Moral lives across cultures. Heterogeneity and conflict. In M. Killen \& J. Smetana (Eds.), Handbook of moral development (2nd ed., pp. 259-278). Psychology Press.

Wainryb, C., \& Turiel, E. (1993). Conceptual and informational features in moral decision making. Educational Psychologist, 28(3), 205-218. https://doi.org/10.1207/s15326985ep2803_2

Wedel, J. (2010). Spiritual afflictions and sorcery accusations among the Miskitu. Anthropos, 105(2), 369-382. https://www.jstor.org/stable/25734809?seq=1

Whitehead, N. L., \& Wright, R. (Eds.). (2004). In darkness and secrecy: The Anthropology of assault sorcery and witchcraft in Amazonia. Duke University Press.

\section{Notes on Contributors}


Guillermo Enrique Delgado has received $\mathrm{PhD}$ in philosophy and magister in psychoanalytic psychotherapy (Complutense University of Madrid. Bachelor of Psychology (Pontificia Universidad Católica del Perú. Associate professor and member of G-CAD, Cognition, Learning and Development research group. e-mail: gdelgado@pucp.edu.pe

Susana Frisancho has received PhD. in developmental psychology, Fordham University, New York. Educational Psychologist, Pontificia Universidad Católica del Perú. Full professor, Department of Psychology, Pontificia Universidad Católica del Perú. Coordinator of G-CAD, Cognition, Learning and Development research group. e-mail: sfrisan@ pucp.edu.pe 